This is a self-archived version of an original article. This version may differ from the original in pagination and typographic details.

Author(s): Hartimo, Mirja

Title: On the Origins of Scientific Objectivity

Year: 2019

Version: Accepted version (Final draft)

Copyright: @ 2018 Routledge

Rights: In Copyright

Rights url: http://rightsstatements.org/page//nC/1.0/?language=en

Please cite the original version:

Hartimo, M. (2019). On the Origins of Scientific Objectivity. In F. Kjosavik, C. Beyer, \& C. Fricke (Eds.), Husserl's Phenomenology of Intersubjectivity : Historical Interpretations and Contemporary Applications (pp. 302-321). Routledge. Routledge Research in Phenomenology. 


\section{On the origins of scientific objectivity ${ }^{1}$}

M irja Hartimo

University of Jyväskylä

Husserl's analysis of the life-world(s) in the Crisis suggests cultural relativism: the "truths" of the inhabitants of foreign worlds may be contradictory to ours. Yet, Husserl believed that in science, that nevertheless is in the life-world, the goal is to establish truths valid for everyone. This gives rise to the topic of this paper: how does Husserl account for scientific objectivity?

In Husserl's last texts several different but interrelated conceptions of objectivity can be found. I will here elaborate them insofar as they play a role in clarifying the origins of scientific objectivity within the subjective-relative life-worlds. After briefly discussing Husserl's notion of life-world and the relativity of the life-worlds, I will examine the sources of objectivity as discussed in Erfahrung und Urteil. For Husserl, the most primitive form of objectivity has its origin in perception. Husserl abstracts from perception what he calls 'simple perception', which is of 'ultimate substrates.' The ultimate substrates make the judgments of perception possible. Husserl's search for them aims at revealing the source of "the original self-evidence" that justifies the validity of the judgments of perception. The relatedness of judgments to the ultimate substrates shows that our judgments are not "freely floating" but are anchored to the pregiven, existing world. The cognitive activity built upon simple perception aims at examining whether the objects truly are as they are pregiven in simple perception. Much of Husserl's analysis of simple perception thus carries over to higher levels of constitution of objectivity: even scientific objectivity ultimately requires a reference to perception of objects and their measurable properties. In addition, in the sciences we strive at coherence that has its roots in striving for harmony that can also be found already in prepredicative perception.

\footnotetext{
${ }^{1}$ I greatly acknowledge the support of Centre for Advanced Study in Oslo, Norway that funded and hosted our research project "Disclosing the Fabric of Reality - The Possibility of M etaphysics in the Age of Science" during the academic year of 2015/16, when the present article was written. Special thanks are due to Frode Kjosavik and Christian Beyer.
} 
But, the experience of objectivity found in perception does not solve the problem caused by the relativity of the life-worlds. Hence, I will next discuss the a priori structure of the life-world that Husserl offers as an answer to the problem of relativity of the life-worlds in Crisis. The structure presupposes many types of intersubjectivity, but I will argue that ultimately it is not able to provide us more than conditions of objectivity: As a common structure of the life-worlds, it does not solve the relativity originating in different life-worlds. To escape the relativism of the life-worlds, and to achieve "cross-world intersubjectivity" a theoretical attitude is needed. It means entering an attitude in which objectivity is taken as a goal. Objectivity now refers to an attempt to form unbiased judgments.

The naive theoretical attitude however is not yet the scientific attitude, which is reflected, selfcritical attitude. It aims at truth, consistency, and unambiguous expression in a self-critical manner as is explained in Formal and Transcendental Logic. Further historical self-reflection is needed to guard against the fact that the scientific attitude may mislead us to have a mistaken and one-sided view of the reality, as is discussed in Crisis at length. I will end the paper by discussing how The Origin of Geometry summarizes Husserl's view of scientific objectivity.

\section{The life-world}

The meaning of Husserl's notion of 'life-world' is context dependent and thus it escapes a univocal definition. Many authors have complained that the notion appears paradoxical, even contradictory: For example, Husserl speaks of life-worlds but also stresses that there is only one 'world'. Accordingly, the notion of 'life-world' has not been understood as one, but as many interrelated and often incompatible notions. (Carr 1970; Steinbock 1995, 87-111; M oran 2012, 178-217; see also Føllesdal 2010, 41-42). To overcome such puzzles I would like to propose approaching the notion of 'life-world' intensionally, in terms of our attitude instead of discussing it in terms of kinds of objects that belong to it. I propose viewing the life-world as whatever we take for granted. Instead of arguing whether the notion is tantamount, say, to the notion of the surrounding world, or discussing whether it includes cultural objects or not, that 
is, discussing it in terms of its extension, I suggest that it should be defined in terms of our attitude of taking something for granted. Being explicitly intensional about the notion enables capturing both the context-dependence of its extension and the intensional common core in the various manifestations of the life-world. The life-world is always what we take for granted in certain situation and hence its extension varies. Sometimes we take for granted only our immediate surrounding world, sometimes it refers to the shared culture, sometimes to the general background, sometimes to a closed particular world. All these manifestations of the life-world can be thought of as instances of free variation of "what we take for granted". ${ }^{2}$ The life-worlds can thus vary from the one that includes one's personal history to the most general, open-ended conception, which we share with undetermined "everyone".

\subsection{The life-world as the surrounding world, as the horizon}

In his published texts (FTL and Crisis) Husserl arrives at the concept of the life-world in his transcendental investigation of the presuppositions of the sciences (FTL §92, Crisis §28). ${ }^{3}$ Accordingly in the Crisis, he criticizes Kant for assuming an unquestioned presupposition:

from the very start in the Kantian manner of posing questions, the everyday surrounding world of life is presupposed as existing - the surrounding world in which all of us [...] consciously have our existence; here are also the sciences, as cultural facts in this world, with their scientists and theories (Crisis, §28).

This manifestation of life-world is "what we take for granted" in the sciences, the presupposition of the sciences. Understood in that way the 'life-world' refers to the background, to the universal horizon that we assume to exist for all of us. Whatever we do

\footnotetext{
${ }^{2}$ This should not be entirely strange thought: there are some considerations of the essence of the world and the free variation of the world in Husserliana XLI (in texts written in 1935, e.g., 373-374; 376-381).

${ }^{3}$ Please, see the end of the paper for the used abbreviations. I will generally refer to paragraph numbers in order to refer simultaneously both to the German original and the English translation of the text. Where it is not possible $I$ have included the letters ' $E$ ' and ' $G$ ' to indicate the publication I am referring to.
} 
takes place in it, and whatever we thematize has it as its ground. In this sense the life-world refers to the surrounding world that contains what we can see and touch to be around us: physical objects, other human beings, and cultural objects (Crisis, §28). The "we" in this notion refers to all normal human beings, with more or less similar sensations and kinestheses as what we have. Indeed, the way in which it relies on our assumption of normal senses and kinestheses suggests that it is something we do not share with babies, the handicapped, or animals. $^{4}$

\subsection{Particular worlds, home-world, and foreign world}

An interesting modification of the life-world as the background is what Husserl calls 'particular world' [Sonderwelt]. In it "what we take for granted" includes also our goals or purposes in life. They determine interested attitudes or vocations we may have:

Thus as men with a vocation we may permit ourselves to be indifferent to everything else, and we have an eye only for this horizon as our world and for its own actualities and possibilities - those that exist in this 'world' - i.e., we have an eye only to what is 'reality' here (what is correct, true in relation to this goal) or 'unreality' (the incorrect, the mistaken, the false) (Crisis, Beilage XVII/Appendix VII).

The particular world [Sonderwelt] is a "social or cultural context, that is organized around a specific purpose" (Kjosavik 2012, 23). It arises with a shared goal or purpose, which creates a hierarchy of purposes. These goals may be long-term or short-term goals, and the particular world can respectively be an enduring one or have a short life span. M any times the goals are such that we actively choose to have them, but we also may drift into having them. Within the particular worlds we have functions, that may become life-long vocations for us. Typically we

\footnotetext{
${ }^{4}$ This is not to say that they are always excluded: Elsewhere Husserl discusses experience community [Erfahrungsgemeinschaft] which may include higher animals, such as dogs (Hua XXXIX, 171-172). He also considers the world of a child consisting of the nursery, house, and possibly part of the street, etc. (Hua XXXIX, 175)
} 
participate in many particular worlds, such as our family, nation, or our profession. Accordingly we may have many vocations: "as normal human beings we are constantly (in a broadened sense) involved in many 'vocations' (interested attitudes) at the same time: we are at once fathers, citizens, etc."(Crisis, §35). They are our functions in the worlds, in which whatever we take for granted we share with the others in that world, whether our family members, fellow citizens, or colleagues. Husserl's view may seem contradictory: while he claims in the above quote that we have an eye only to what is 'reality' in one particular world, he also claims that we have many such vocations and thus belong to many particular worlds. It is useful here to remind oneself of the intensionality of the notion of 'world' for Husserl: For Husserl being in a particular world is a matter of attitude and when we are in it that particular world is the "reality" for us. By a shift of an attitude we may change to another particular world. For example, we may have an eye only to what is "reality" at work, but we may, at any time, shift our attitude to being in the world in which we are fathers or citizens. We may also shift our attitude to the one in which we think of our life as a whole so that it includes the particular worlds we may participate. Within that attitude we can say that we are at once in many particular worlds. Indeed, Husserl claims that every vocation has "its proposed time" within the one personal time, that is the "form of the various exercised vocational times" (Crisis, §35).

All these particular worlds belong to our home-world. It is the familiar world in which, due to (more or less unified) upbringing, we take for granted the shared tradition (Hua XXXIX, 161). Within the home-world the particular worlds of which I am not a member have types that are unknown to me, but which I know I could learn to know through instruction [Belehrung] from others (Hua XXXIX, 160). In other words, in our home-world we have a capacity to learn from others the expertize required in the particular world and thus we have an experience that in principle we could join it. ${ }^{5}$

\footnotetext{
${ }^{5}$ Husserl gives an example how we, as if from the outside, relate to the army and the military environment. When one volunteers to serve in the army, one learns a typification of behavior, ways of speaking, practical reactions, and so forth. One might learn to behave in accordance to to the type of the military vocation, but one would still lack the full understanding that one would have, had he been raised into it and built his personality in accordance to it. (Hua XXXIX, 161). Husserl's distinction between foreign world and the particular world that we view externally in terms of the possibility to become an expert in it suggests that for example for the disabled the world of the "normal" people is in certain aspects foreign rather than externally viewed particular world.
} 
Husserl juxtaposes the experience of being able to acquire the required expertize and enter a particular world with the experience of the foreign worlds. We do not have the same experience of the foreign worlds that I cannot directly understand with full confidence:

Über diese Welt hinaus habe ich Erfahrung von 'Fremden', die ich nicht voll verstehen, sondern nur indirekt verstehen kann als M enschen einer Umwelt, die die ihre, aber nicht die meine ist, ohne Fähigkeit, sie zu befragen oder sonstwie zu einem Ausgleich kommen zu können (Hua XXXIX, 161).

We can understand the foreigners only indirectly as people in their environment about which we are incapable to get in terms with. Since we do not share the tradition and in particular the upbringing of the foreign culture Husserl claims that we can never fully understand it. We do not fully know its typification: I cannot tell whether the building in front of me is a temple or a government office (Hua XXXIX, 159). According to Husserl, to understand the world of, for example, the Chinese, we must learn its typification as if we were children:

Wie ich als Kind hineinerzogen wurde in meine generative M enschenwelt, so muss ich, wenn ich den Chinesen und die chinesische Welt verstehen will, [in diese] hineinerzogen werden; ich muss hineinlebend mir die Apperzeption der fremden Welt, wie immer und wie weit das möglich ist, erwerben, was so viel hieße wie: immer vollkommener chinesischer M ensch unter Chinesen werden - während ich noch Deutscher bin und meine deutsche Umwelt nicht verliere. Und ebenso der Chinese in meiner Welt (Hua XXXIX, 162).

While we cannot acquire complete understanding of the foreign world, to some extent it is always possible to understand it, since we nevertheless know that we live in one and the same world (Hua XXXIX, 163). Understanding a foreign world takes place on the basis of our understanding of our homeworld by using analogies and examining what is similar and what is dissimilar and what we cannot understand. Thus we'll find in a foreign world a kernel that is quite similar to our home-world. What we cannot understand we can view as a modification of our home-world: 
Sie sind für mich analogisch verstanden, aber ganz unbestimmt allgemein, und nach ihren Bestimmtheiten einfach unbekannt. Sie verweisen auf fremde Personen, deren Akte ich in einer Kernsphäre wirklich verstehe und mit einem Kern ihre Gegenständlichkeiten. Und da muss ich, weitergehend, rekonstruieren können, was für bleibende Interessen, Zwecke, Werkzeuge sie für ihr zweckmäßiges Hantieren etc. haben und sich geschaffen haben et. (Hua XXXIX, 168).

Thus the foreign world is necessarily a reconstruction on the basis of our home-world (Hua XXXIX, 167-168). Encounter with the others in general extends our understanding. However, we do not only learn about others as people in the world, about our home-world and about the world in general, but we belong to a community of experience [Erfahrungsgemeinschaft] with the others and within it into a community of thinking [Denkgemeinschaft]: In it we consider the foreigners as fellow beings [M itsubjekte] with whom we know the world. (Hua XXXIX, 171-172.) In Crisis, Husserl explains that in the life-world we arrive at "secure" facts, "undisturbed by any noticeable disagreement" (§36). Similarly in the foreign worlds the foreigners may have their "facts". Husserl writes,

"when we are thrown into an alien social sphere, that of the Negroes in the Congo, Chinese peasants, etc., we discover that their truths, the facts that for them are fixed, generally verified or verifiable, are by no means the same as ours" (Crisis, §36).

Husserl thus postulates facts and truths that are relative to a life-world. Husserl here extends his intensional way of speaking of life-worlds to truths and facts. Instead of truths or facts, Husserl really talks about attitudes "holding as true" and "holding as a fact" within a life-world, i.e., in the context of "what we take for granted". These intensional attitudes take place within a life-world and even if they were verified and uncontested within the life-world in question they may not be the same as in another life-world. Having read Levy-Brühl Husserl presumably has in mind of "facts" such as that a certain lion is in fact somebody's cousin, which is something we would not take as a fact. Husserl however does not clearly make the difference between "holding true" and "true", which makes Husserl's view appear to be that truth is 
culturally determined. Husserl, however, is not a relativist. The topic of the remainder of the paper is to examine how Husserl thinks we escape the cultural relativism brought about the lifeworlds.

\section{Sources of objectivity in perception}

\subsection{Ultimate substrates}

First, Husserl's analysis of perception in the Erfahrung und Urteil shows that there is something transcendent, something that we do not construct and that we are directly in touch with in perception. There is purely sensuous ground that is a source of 'objective evidence' [gegenständlich Evidenz] in contrast to the evidence of a judgment [Urteilsevidenz]. It is evidence with which the objects of judgments are given. According to Husserl,

[o]bjects are always present for us, pregiven in simple certainty, before we engage in any act of cognition. At its beginning, every cognitive activity presupposes these objects. They are there for us in simple certainty; this means that we presume them to exist and in such a way as to be accepted by us before all cognition, and this in a variety of ways $(E U, \S 7)$.

The object given prior to any epistemic activity is what Husserl calls an 'ultimate substrate'. Isolating it from objects of our perception is not a straightforward task, since the lifeworld is invested with sense to the extent that it is difficult to isolate what is given prior to any sedimentations of sense (EU, §11). Hence, Husserl also claims that the ultimate substrate is given as a dynamis, which in cognitive activity turns into an entelecheia (EU, §7).

To reach a pure sensuous perception we need to peel off what in our experience involves understanding of an expression. Expression is not restricted to linguistic expression, but understanding of an object as something cultural. According to Husserl, to attain the ultimate substrates we should not think, for example, of a hammer as a tool, but as a sensuous identity in space and time; we should not relate to other human beings as persons, but focus only on 
the sensuous perception of the corporeal element that founds the more encompassing perception of the body being a person, or an animal.

In order to attain the truly ultimate and original self-evidence of prepredicative experience, we must go back from these founded experiences to the simplest, and thus leave all expression [Ausdruck] out of play. For every experience which finds the existent determined otherwise than by its natural qualities, and identifies it as an implement or what have you, refers to an understanding of expression. Accordingly, we leave as valid only pure sensuous perception and then experience in general; we look upon the world purely as a world of perception, and we abstract from everything which it manifests in itself as regards familiarities and determinations which are not rooted in purely perceptive acts but in evaluative ones, ours as well as those of others. In this way, as the ground of experience, passively pregiven, we obtain pure universal nature, which in the natural sequence of sensuous perception is given as a closed system, as precisely the nature which I perceive and have perceived - for, from the actual field of my experience, I have excluded others by putting all expression out of action. For the concretely existing world, this putting out of action signifies an abstraction - a word which at first is meant to express only a proximal leaving out of account of things which are there for me and continue to hold good (EU, §12).

These ultimate substrates are given in pure perception. The pure sensuous perception of objects is thus reached by abstracting from all expression in our own or others' experiences. The ultimate substrates are mere sensuous bodies with determinations like shape, size, color, etc., that are "rooted in purely perceptive acts" (see also EU, §29). As contents from which all 'expression' is abstracted away the purely sensuous contents are the source for objectivity and hence somewhat paradoxically for intersubjectivity.

The objects of pure sensuous perception are ultimate substrates that are natural bodies passively given in the protodoxa [Urdoxa], which gives us simple certainty of them being there. They give us preknowledge [Vorwissen] that is indeterminate as to content, but never completely empty. But without it, "the experience would not at all be experience of this one, 
this particular, thing" (EU, §8). They give the possibility to further determine them in further experience. It is only on a higher level that the existent becomes confirmed in judgments, and thus becomes a permanent possession of knowledge (EU, §13).

These absolute substrates belong to a world, so that in the simple perception the external world is given to us. The simple substrates are still constituted by us so the world that they give to us is mind-dependent. However, they also fix our experiences to be about this particular thing "truly given as 'itself-there,'" (EU, §8), that is, they anchor our experiences to be about the world, about something transcendent.

\subsection{Perceptual harmony}

Another aspect of experience that plays a role in our experience of the world is what Husserl in the Erfahrung und Urteil refers to as the "self-preservation of the ego". Thanks to it, we have what Husserl calls "perceptual harmony". The aspiration to harmonious experience determines our perception already when we start looking at an object. Due to it there is "a moment of the striving which belongs to the essence of normal perception" (EU §20). Consequently, our experience of the world is not a discrete set of flashes of perceptions of objects, but in order for us to have the world our perceptions have to be unified, and if needed, corrected. Accordingly, perceptions of objects have their horizons of future and past: perception of an object makes us anticipate what we are going to perceive next. Likewise, we retain an idea of what we just perceived (Hua VIII, 51). Tyler Burge (2010) discusses similar phenomena under the term 'perceptual constancy'. For example, we have a capacity to see a color of a surface as constant independently of the way it is lid up; likewise we see a shape and a size of a thing as constant even though our perspective to it changes, and so forth.

In Husserl's analysis, the striving for harmony is at work at every level of constitution, from the passive syntheses to the active ones, including the origins of logic. At the level of judgment, for Husserl, the general striving of the ego becomes striving for consistency of judgment and for certainty. Making judgments about the objects is ultimately making decisions about how things are. These decisions are, however, "completely dependent insofar as they have their motivational foundation in what takes place in the perception itself, in its proper and perhaps 
purely passive course" (EU, §71). We cannot freely decide that an object is red if it is green. But, we have a need to decide something, and we cannot decide that the object is both green and red, because we have to maintain "perceptual harmony" [Wiederherstellung der Einstimmigkeit der Wahrnehmung].

"The motivational foundation in favor of a decision which is a firm positing-as-valid by the ego, or in favor of a corresponding negative decision, is the re-establishment of perceptual harmony [Wiederherstellung der Einstimmigkeit der Wahnehmung]. The split and the conflict of the perceptual apprehensions mutually displacing one another is returned to an unbroken unity. The ego is affected by all this; it itself, as ego, and in its own way, is disunited with itself, is divided, and is finally reunited. " (EU, 290, translation modified).

Inconsistent decisions about the objects of perception would make our ego "to split" at once to think that the object is red, and in the next moment to deny it. It would break the anticipatory, horizonal, structure of experience. The conflict is even more obvious in the cases where different perceptual organs give conflicting 'reports' at the same time, like in the case of malfunction of one of the senses. In that case all other senses 'fill in' and furnish "a world progressing harmoniously" (Ideen II §18). The conflicting sense experience would pull apart our sense of ourselves. According to Husserl, this would mean scattering of the ego. Hence, the tendency of our ego is to unify the experiences:

If the perceptual harmony is re-established, if a single perception again unfolds in normal form, then the internal conflict of the ego with itself is resolved. The ego can no longer be inclined now in this direction, now in that; the nullified apprehension with its nullified intentional tendencies, above all with its still living, still dynamic, but canceled expectations, can no longer be carried out. M oreover, the field in which the ego now operates is not only the horizon of free expectation and the intentionality now established in unanimity; the ego also actively takes a position on this ground, adopts what is given in harmony as existing absolutely (EU, $§ 71$, translation modified). 
Our life is pervaded by a striving for consistent experiences. Perception of objects is unthinkable without the constancies. To sustain a stable conception of ourselves and the world, we need to strive to consistency and certainty about some experiences. This striving takes place on various levels all the way from passive perceptions up to scientific practice. Thus we strive to perceive things correctly to maintain some unity about ourselves and the world in which we live: "Striving for consistency of judgment and for certainty is thus a characteristic which is part of the general striving of the ego for self-perservation" (EU, §71).

According to Husserl, on a higher level, this act of striving becomes a will to knowledge (EU, §20). It is something that we, human beings, as rational beings do. The striving for scientific knowledge is the higher order version of this same striving. ${ }^{6}$

In general, many aspects of Husserl's analysis of simple perception carry over to higher levels of constitution. As discussed above, this is very much the case with the general striving of the ego. In addition, for example, Urdoxa connected to ultimate substrates turns into a naïve trust in the existence of the lifeworld. What is constituted as ultimate substrates at the lowest level is constituted as spatio-temporal conceptualized objects in the life-world. And, as Husserl specifies in the "Origin of Geometry" "what counts as primal self-evidence [Urevidenz] for the sciences is determined by an educated person or a sphere of such persons who pose new questions, new historical questions, questions concerning the inner depth-dimension as well as those concerning an external historicity in the social-historical world" (Crisis, 381G/373E).

\section{Formal conditions of the objectivity}

In the Crisis, having discussed the relativity of the life-world, Husserl starts to wonder what could be established once and for all and for everyone. What he arrives at is the general structure of the life-worlds. This "general structure, to which everything that exists relatively is bound, is not itself relative. We can attend to it in its generality and, with sufficient care, fix it once and for all in a way equally accessible to all” (Crisis, §36). Husserl explains that these categorical features of "the life-world have the same names but are not concerned, so to speak,

\footnotetext{
${ }^{6}$ Hence, pace Zahavi $(2003,135)$, disagreement is not the only motivation for engaging in scientific research.
} 
with the theoretical idealizations and the hypothetical substructions of the geometrician and the physicist" (Crisis §36). They are structures that need to be in place so that we can have knowledge of a world, whether scientific or a life-world, or is put in Erfahrung und Urteil, "the structure of the known and of the unknown is a fundamental structure of world-consciousness, correlatively, a structure of the world as horizon of all individual real things capable of being experienced." (Crisis $\S 8) .7$

What then does belong to this a priori structure? According to this structure the world is a universe of spatio-temporal things that have a spatial and temporal position, in causal relationships with each other, and the world is spatiotemporally infinite (Crisis, §36). In the next paragraph, Husserl adds that the world is given as a horizon. Further, it is pregiven in such a way that individual things are given. The objects are given within the "world-horizon", i.e., we never encounter mere isolated objects, but they are grasped in the background of the world. Each object is something, "'something of' the world of which we are constantly conscious as a horizon" (Crisis, §37). In other places, when explaining the structure, Husserl explains that each object belongs to a type (cf., e.g., EU, §8). The perception has a temporal structure, it has an open future in front of it and an endless past behind it (Crisis, §46). It requires kinestheses, i.e., the sense of one's own body, which is required, for example, to determine, on the basis of the movements of our eyes, whether a perceived object is near or far (Crisis, §47). Further, we experience the things to belong to types of various levels, and we anticipate the things to have further determinations in accordance to their types (EU, §8). M oreover, all perception of generality or plurality is founded on acts of perceiving individuals, hence the original substrate

\footnotetext{
${ }^{7}$ Husserl writes: "As life-world the world has, even prior to science, the 'same' structures that the objective sciences presuppose in their substruction of a world which exists 'in itself' and is determined through 'truths in themselves' ...; these are the same structures that they presuppose as a priori structures and systematically unfold in a priori sciences, sciences of the logos, the universal methodical norms by which any knowledge of the world existing 'in itself, objectively' must be bound" $(C, \S 36)$. This may not be true of the way in which contemporary physics approaches the world. Phenomenology however is not immune to the development of sciences, hence if Husserl was writing today, he probably would not claim that the physicists presuppose the objective world of physics to share the a apriori structure of the life-world. In the Ideen II, Husserl describes the things of the physicalistic nature as follows: "the thing itself in itself consists of a continuously or discretely filled space in states of motion, states which are called energy forms. That which fills space lends itself to certain fundamental laws of physics." (Ideen II, §18g).
} 
has to be an individual object (EU §5). The objects are given in various modalities (i.e., as probable, as imagined, as certain, etc.). These modalities turn out to be modifications of "an original simple believing consciousness" [M odifikationen eines ursprünglichen schlichten Glaubensbewußtseins] (EU §7; Crisis, §§ 37, 38), in which the objects are first given to us. Husserl describes the structure as an achievement of prepredicative experience (EU §8). That means that the general structure of the life-world is founded on perceptual and judgmental harmonies discussed above. As structures of any life-world, they are structures of what is taken for granted. Thus, instead of "ultimate substrata," objects at stake typically include cultural objects and other people. They belong to the familiar types of the life-world in question. The "expression" is certainly included in the apriori of the life-world. The objects are taken for granted among the "we" of the life-world, whether, say, normal people in general or only those who live in the same village.

M uch of Husserl's discussions of transcendental intersubjectivity relate to the intersubjectivity within the life-world. For example, the life-world objects are obviously public and they are experienced as accessible to everyone. That there are other people requires empathy for me to recognize the others as embodied subjects. All this presupposes prior open intersubjectivity, i.e., reference to others whether I experience them or not. In a life-world what is considered as normal provides a norm for our judgments. Furthermore, experiences of the normal members of the community are relevant for solving disagreements about our experiences (See, e.g., Zahavi 2003, 110-115; 119-120; 133-134).

But, as we saw above, there may be life-worlds that, despite of the same general structure, have conflicting "truths" about the world. The general structure thus does not save us from relativism. The rudimentary objectivity that originates in perception may still be conceptualized in contradictory ways, relative to the life-world in question. This is because the normality that belongs to our homeworld may conflict with a foreign normality (Zahavi 2003, 135). This shows that the intersubjectivity within a life-world cannot be equated with objectivity. Or else, one has to admit different kinds of objectivity as Dan Zahavi does: he distinguishes between the objectivity that suffices in daily life and that might be correlated to a certain limited 
intersubjectivity, and "'rigorous' or scientific objectivity, which is unconditionally valid for all subjects" $(2003,135-136)$.

\section{Overcoming relativity of the life-worlds by theoretical attitude}

Some clues as to how we could overcome the relativity of the life-worlds and how we can attain objectivity that is unconditionally valid for all can be found in the paragraph already cited above:

But if we set up the goal of truth about the objects which is unconditionally valid for all subjects, beginning with that on which normal Europeans, normal Hindus, Chinese, etc., agree in spite of all relativity - beginning, that is, with what makes objects of the life-world, common to all, identifiable for them and for us (even though conceptions of them may differ), such as spatial shape, motion, sensequality, and the like - then we are on the way to objective science. When we set up this objectivity as a goal (the goal of a 'truth in itself') we make a set of hypotheses through which the pure life-world is surpassed (Crisis, §36).

Husserl suggests that we escape the relativism of the life-worlds by choosing unconditionally valid truth for all subjects as our goal within the general a priori structures. Thereby, Husserl claims an intersubjective agreement about what objects there are and what, typically measurable, qualities they have. This is what takes place in what he elsewhere describes as theoretical attitude. In a theoretical attitude one is directed "with an active focus to what is objective, ... in a specifically intentional way. Again, it is one thing to be conscious at all that the sky is blue, and it is another thing to live in the performance of the judgment (that the sky is now blue) in an attentive, explicitly grasping, specifically intentional way" (Ideen II, §3). Husserl further describes the attitude to be objectifying in the sense that in it an objectivity is grasped and posited. In Formal and Transcendental Logic Husserl characterizes it as an interest in verification, that is, a need to convince oneself by the affairs themselves of "how they actually are" (FTL, §44bß). 
According to Husserl in the above paragraph, we "make a set of hypotheses through which the pure life-world is surpassed". We try to overcome the relativity of our life-world by thinking about what is common to everyone irrespective of the life-world they are in. We then think about the things as physicalistic things, that is, objects that can be similarly known by any cognizing subject. The kind of objectivity at stake here is thus characterized by an attempt to make unbiased judgments, a judgment that is true for everyone. Such an attempt requires considering other points of view. This presumably requires experience of the transcendence of foreign subjectivity. (See Zahavi 2003, 115, also Kjosavik, unpubl. manuscript). In any case, empathy is presupposed. Husserl writes, "he must experience the things and the very same things, and he must, if he is also to know this identity, stand in a relation of empathy to the other cognizing subjects, and for that he must have corporeality and belong to the same world, etc. " (Ideen II, §18f). However, making unbiased judgments does not yet yield scientific objectivity.

\section{Scientific Objectivity}

In Formal and Transcendental Logic Husserl considers communities of judgers, for whom, for example, nature is not nature for me, but nature for us, or nature for us natural scientists, or nature for the natural science of our times (\$42f). He thus postulates levels of objectivity depending on how encompassing the community of judgers is. One could describe the worlds of the communities of judgers as different particular worlds, in terms of Crisis. In particular, in the scientific particular world the "we" in "what we take for granted" ranges over "everyone as a rationally thinking subject" (FTL §44bץ).

But, there also additional differences between the everyday interest in truth and scientific judgments. In an everyday judging the judger goes on accepting the judged objectivity. In it the object and its relationships to other objects are actually given (FTL $₫ 44 b \beta)$. The scientific judger, on the other hand, 
lives a "theoretically interested" life, with vocational consistency. That is to say, his vocational judging is always ruled completely by intentions aimed at cognition; and these themselves have their synthetic unity: namely in the unity of the cognitional interest directed to the scientific province in question. In the strict sense ..., cognizing his province signifies, for the scientist, nothing else but accepting no judgments as scientific results except those that have shown their "correctness", their "truth", by an adequation to the affairs themselves and can be produced again originaliter, at any time, with this correctness - that is to say, by a reactualizing of the adequation. (FTL $\S 44 b \gamma)$.

Crucial to the scientific attitude is the idea that the results of experiments can be reproduced by anyone, at any time. This brings certain methodological systematicity to the judgments about truth. Husserl's reference to "vocational consistency" suggests that the scientist has acquired expertize about the methods to be used. Furthermore, in the sciences the scientists' prior judgements are considered only as provisional, not as lasting acquisitions. While the nonscientific judger 'merely looks and sees' whether something is actually thus or so, the scientist considers the possibility of being deceived:

Consequently there exists for him the further distinction between supposed and genuine evidence. His judgments must be verified by genuine, by maximally perfect, evidence; and only as so verified shall they be admitted among the results of science as theory. This brings about a peculiar judging procedure on the scientists's part, a zigzag judging, so to speak: first making straight for the givenness of something itself, but then going back critically to the provisional results already obtained - whereupon his criticism must also be subjected to criticism, and for like reasons. Thus the scientist is guided by the idea of an evidence that is perfect or perfectible by systematic stages, and attainable by means of criticism, an evidence having as its correlate an attainable, or approachable, true being (an idea, incidentally, the sense and limits of which are not matters for positive science itself to explore). " (FTL, §44bץ). 
The scientist regards his judgments as fallible. Thus the notion of truth acquired in the sciences is a critical notion of truth as opposed to truth as actuality or verification in the everyday judging (FTL,§46). In what could be called a 'scientific particular world' the theoretical attitude is not naïve, but self-critical and able to justify its methods and theory to conform to the constitutive values and norms of sciences (FTL, 1).

The scientist aims to make judgments that are expressed unambiguously, are coherent and are critically warranted in light of evidence. The aim is to describe the world correctly. This presupposes a number of idealizations. In many of his writings Husserl emphasizes the Euclidean ideal that he thinks provides the exact sciences an ideal of how their truths should be systematized. Ultimately, however, the normative structure of the sciences includes a reduction to judgements about individuals. This means that the scientific theories are ultimately based on judgements about individuals in the life-world, and ultimately they draw their evidence from the concrete objects of perception. Husserl writes for example that:

To the reduction of judgments to ultimate judgments with an ultimate sense, there corresponds a reduction of truths: of the truths belonging to a higher level to those belonging on the lowest level, that is: to truths that relate directly to their matters and material spheres, or (because the substrates play the leading role here) that relate directly to individual objects in their object spheres - individual objects, objects that therefore contain within themselves no judgment-syntaxes and that, in their experienceable factual being, are prior to all judging. That judgments (not judgmentsenses) relate to objects signifies that, in the judgment itself, these objects are meant as substrates, as the objects about which something is stated; and reductive deliberation teaches, as an Apriori, that every conceivable judgment ultimately (and either definitely or indefinitely) has relation to individual objects (in an extremely broad sense, real objects), and therefore has relation to a real universe, a "world" or a world-province, "for which it holds good".(FTL§83). 
In the Crisis Husserl adds to his consideration of the sciences the life-world in which the scientist makes his judgments and thus the practice of science. On the basis of their life-world experiences the scientists aim at finding out what the objective reality is like. According to Husserl, the objective reality as such is not experienceable; we only experience particulars in the life-world. Husserl holds that the

experienceability of something objective is no different from that of an infinitely distant geometrical construct and in general no different from that of all infinite 'ideas,' including, for example, the infinity of the number series (Crisis, §34d).

The objective reality remains a goal, a normative ideal, that is constantly pursued but never reached. Our construction of reality is based on judgments about individuals in the life-world. On the basis of our life-world experiences the scientists construe an account what the world of physics really is like. Fallibility of judgments makes the scientist as described in the FTL critical towards his own judgments. In the Crisis Husserl extends the critical aspect and extends the criticism also to the scientific method itself. He writes:

[w]e ourselves, who are carrying out these reflections ..., stand under the spell of these times. Being caught up in them, we at first have no inkling of these shifts of meaning we who all think we know so well what mathematics and natural science 'are' and do (Crisis, §9l).

We may think that we know what the sciences are, but in our 'knowledge', we may be "caught up" under the spell of the time. In spite of our efforts to reach objective truths we may be misguided in ways that we are not noticing. Especially, we might think that the world is given to us as something that can be described and controlled by the exact methods of mathematical physics. The Euclidean ideal guiding our idealizations may mislead us:

This idea of the world as a universe of being, capable of being controlled by the exact methods of physicomathematical science, of a universe determined in itself, whose factual determinations are to be ascertained by science, is for us so much a matter of 
course that we understand every individual datum of our experience in its light (EU, $\S 10)$.

The Galilean idea to mathematize nature gives a 'garb of ideas' [Ideenkleid] through which we take for true Being, what is actually a method, "and this causes us to interpret the world of our experience always according to the sense of this garb of ideas thrown over it, as if it were thus 'in itself.'" (EU, §10). The idea is misleading because it is not applicable to the domains where the essences are morphological. The latter essences are the fluid and vague ones in the domains related to persons and consciousness; Husserl criticizes applying the exact methods on human affairs already in Ideen I (\$74). Illegitimate ascription of exactness is a typical case of illegitimate shift of meaning, which thus necessitates historical self-reflection.

\section{Wrapping up: the "Origin of Geometry"}

The "Origin of Geometry," I believe, nicely summarizes everything discussed above. In it, Husserl engages in a thought-experiment in which he tries to secure the original self-evidence that belonged to the first creation of geometry. Whereas in Erfahrung und Urteil he attempted to isolate pure experience "untainted by expression", this time he wants to find the origin of objectivity that is unaffected by the Galilean, or Euclidean ideal. Thus his examination of the origin of geometry aims at capturing the notion of objectivity stripped from the 'garb of ideas' given to it by the tradition of geometry and Galilean physics. In so doing, he aims to take into account the origin of objectivity independently of scientific idealization, thus he radicalizes his earlier analyses. Contrary to the typical way of reading the "Origin of Geometry" as a reminder of the subjective and historical origin of the sciences, I would thus like to view it as an examination of the ahistorical origins of objectivity. For that reason Husserl now engages in generative, historical analysis of the layers of sense to reveal the ahistorical origin, untainted by e.g., the Euclidean ideal, of objectivity. The generative analysis shows the layers that have to be 
peeled off from our experiences to find the ahistorical origin untainted by shifts of meaning due to our historicity. ${ }^{8}$

In Husserl's generative analysis new conditions for intersubjectivity of the geometrical discoveries arise: namely, empathy and language. These are required to communicate the personal discoveries to other people (Crisis, 371G/360E). Further, written language is needed to make the results persist over different historical periods and geographical places.

Language brings with it the possibility of the "seduction of language", that is, that we adopt the results passively without really understanding them. This danger is avoided if one makes sure that what one adopts can be rendered self-evident. Here one has to rely on the scientists whose responsibility it is that what they state as true can be reactivated.

In accord with the essence of science, then, its functionaries maintain the constant claim, the personal certainty, that everything they put into scientific assertions has been said 'once and for all,' that it 'stands fast,' forever identically repeatable with selfevidence and usable for further theoretical or practical ends - as indubitably reactivatable with the identity of its actual meaning (Crisis, 373G/362E).

Given that the geometers rely on the work of previous geometers, the search for the original self-evidence means that its historical tradition has to be disclosed. To escape the cultural relativism created by the thought that every culture has its own 'logic', Husserl holds that the structures should be based on free variation that runs through all conceivable possibilities. The method produces an invariant universal structure, that can be made self-evident at any time,

\footnotetext{
${ }^{8}$ Ian Hacking (2010) has also raised sekpticism about finding any 'deep' sources of objectivism in the origin of geometry. It should be kept in mind that Husserl's interest in the primal beginnings is not 'romantic' nor 'foundational' but it is for the purpose of discussing objectivity unbiased by scientific idealization. If we want to reach the notion of 'thing' independent of the sciences, one has to either examine pure perception or else go back in history. Despite of his criticism, Hacking seems to realize this and writes how on Husserl's view physical scientists after Galileo "work unwittingly in bad faith; theirs is the unhappy consciousness. Only a return to primal sources, to the Ursprung, will liberate them. In particular, we shall regain a full sense of the objectivity of the sciences by comprehending the source, the originary evidence, for this objectivity" $(2010,71)$. Hacking criticizes not only Husserl's project at large, but also the thought that Galileo's mathematization culminating in differential calculus of Leibniz and Newton made the geometry to be about ideal objects. Hacking thinks Husserl should have focused on acts of proving instead of objects $(2010,72)$. As the analysis of pure perception shows, Husserl speaks of objects, since the basic source of objectivity is in perception of objects for him.
} 
any place (Crisis, 383G/375E). Like in Husserl's assessments before, the structure shows that the world of the first geometers was the world of 'things'. All things have a bodily character and they have measurable qualities:

What is also clear, and can be secured at least in its essential nucleus through careful a priori explication, is that these pure bodies had spatio-temporal shapes and 'material' [stoffliche] qualities (color, warmth, weight, hardness, etc.) related to them. Further, it is clear that in the life of practical needs certain particularizations of shape stood out and that a technical praxis always [aimed at] the production of particular preferred shapes and the improvement of them according to certain directions of gradualness (Crisis, 384G/375E).

As before, they, too, had spatio-temporal shapes and certain qualities. Husserl now regards essences having their "normative pull" in practical ideals, not in exact ideals of the Galilean mathematized science. Indeed, the Galilean ideal could not survive the variation across the historical periods. Instead, we can come up with an intersubjective agreement about many determinations such as shapes, whether they are smooth or not, whether the lines are straight or not, etc., because of practical reasons shared by all cultures. Husserl also holds that measurements of quantities are something we should be able to agree on: "M easuring belongs to every culture, varying only according to stages from primitive to higher perfections." (Crisis, 384G/376E). Husserl's conclusion then is that:

"Only [through the disclosure of this a priori] can there be an a priori science extending beyond all historical facticities, all historical surrounding worlds, peoples, times, civilizations; only in this way can a science as aeterna veritas appear. Only on this fundament is based the secured capacity of inquiring back from the temporarily depleted self-evidence of a science to the primal self-evidences" (C 385G/377E).

The intersubjective basis of the sciences is thus in the evidence originating in the experiences of the human surrounding world and in perception of material objects in it. This however is not a basis in any foundational sense. Rather, it gives the boundary conditions for the scientific 
idealizations. For the correctness of the latter, continuous self-critical and historical reflection is the final arbiter of truth.

\section{Conclusion}

In this essay I have examined the sources of objectivity within the subjective-relative lifeworlds. For Husserl, ultimately, the sciences and the scientific method offer the most developed way out of such relativity. However, even the scientific objectivity ultimately refers to simple perception of ultimate substrates and the perceptual and judgmental harmony, which gives validity to its claims. Our judgments are connected to the world thanks to their reference to the objects of simple perception. Instead of the simple belief in the world, the scientific judgments are made with a critical interest in truth and coherence within the scientific particular worlds in service of truth. Furthermore scientific method and its normative ideals should be subjected to a continuous critical historical self-reflection. Thus in Husserl's analysis the sources of objectivity are many: perception of objects, striving for harmony, theoretical and professional interest in truth and self-criticism.

Abbreviations:

Crisis Husserl, Edmund. Die Krisis der europäischen Wissenschaften und die transzendentale Phänomenologie. Eine Einleitung in die phänomenologische Philosophie. Herausgegeben von Walter Biemel. Husserliana Band VI. Haag: M artinus Nijhoff, 1976. English translation: The Crisis of European Sciences and Transcendental Phenomenology. An Introduction to Phenomenological Philosophy. Translated by David Carr. Evanston: Northwestern University Press, 1970.

EU Husserl, Edmund. Erfahrung und Urteil. Untersuchungen zur Genealogie der Logik. Redigiert und herausgegeben von Ludwig Landgrebe. Hamburg: Felix M einer Verlag. 1972. English translation: Experience and Judgment. Translated by James S. Churchill. Evanston: Northwestern University Press, 1973. 
Hua XVIII Erste Philosophie (1923-24) : 2. Teil: Theorie der phänomenologischen Reduktion. Edited by Rudolf Boehm. The Hague, Netherlands: Martinus Nijhoff, 1959.

Hua XXXIX Husserl, Edmund. Lebenswelt. Auslegungen der Vorgegebenen Welt und ihrer Konstitution. Texte aus dem Nachlass (1916-1937). Herausgegebenen von Rochus Sowa. Hua Band 39. Dordrecht: Springer, 2008.

Hua XLI Husserl, Edmund. Zur Lehre vom Wesen und zur Methode der eidetischen Variation : Texte aus dem Nachlass ; (1891-1935). Herausgebenen von Dirk Fonfara. Hua Band 41. Dordrecht, Springer, 2012.

Ideen I Ideen zu einer reinen Phänomenologie und phäneomenologischen Philosophie. Erstes Buch. Allgemeine Einführung in die reine Phänomenologie. Herausgegeben von Walter Biemel. Husserliana Band III. M artinus Nijhoff, Haag 1950. English translation: Ideas Pertaining to a Pure Phenomenology and to a Phenomenological Philosophy. First book. General Introduction to a Pure Phenomenology. Martinus Nijhoff, The Hague, Boston, Lancaster 1983.

Ideen II Ideen zur einer reinen Phänomenologie und phänomenologischen Philosophie. Zweites Buch: Phänomenologische Untersuchungen zur Konstitution. Edited by M arly Biemel. Husserliana Band IV. The Hague, Netherlands: M artinus Nijhoff, 1952. English translation: Ideas pertaining to a pure phenomenology and to a phenomenological philosophy. Second book, Studies in the Phenomenology of Constitution. Translated by Richard Rojcewicz and André Schuwer. Dordrecht, Boston, London: Kluwer. 1989.

FTL Formale and transzendentale Logik. Versuch einer Kritik der logischen Vernunft. Husserliana Band XVII. Edited by Paul Janssen. M artinus Nijhoff, The Hague, Netherlands, 1974. English translation: Formal and Transcendental Logic, transl. by Dorion Cairns. Martinus Nijhoff, The Hague 1969. 
Burge, Tyler. Origins of Objectivity. Oxford, New York: Clarendon Press. Oxford University Press, 2010.

Carr, David. Husserl's Problematic Concept of the Life-World. American Philosophical Quarterly. 1970, 7 (4): 331-339.

Føllesdal, Dagfinn. The Lebenswelt in Husserl. In Science and the Life-World. Essays on Husserl's 'Crisis of European Sciences'. Edited by David Hyder and Hans-Jörg Rheinberger. Stanford, California: Stanford University Press, 2010. 27-45.

Hacking, lan. Husserl on the Origins of Geometry. In Science and the Life-World. Essays on Husserl's 'Crisis of European Sciences'. Edited by David Hyder and Hans-Jörg Rheinberger. Stanford, California: Stanford University Press, 2010. 64-82.

Kjosavik, Frode. Revue Internationale de Philosophie, 2003, 2: 193-202.

Kjosavik, Frode. A Phenomenological Approach to Intersubjectivity in the Sciences. In Fricke and Føllesdal (eds). Intersubjectivity and Objectivity in Adam Smith and Edmund Husserl. Frankfurt, Paris, Lancaster New Brunswick: Ontos Verlag, 2010. 17-44.

Kjosavik, Frode (unpublished manuscript). The scope of the social - Husserl on intersubjectivity

M oran, Dermot. Crisis of the European Sciences and Transcendental Phenomenology. An Introduction. Cambridge, New York, M elbourne, Madrid, Cape Town, Singapore, São Paulo, Delhi, Mexico City, 2012.

Steinbock, Anthony. Home and Beyond: Generative Phenomenology After Husserl. Evanston, Illinois: Northwestern University Press, 1995. 
Zahavi, Dan. Husserl's Phenomenology. Stanford, California: Stanford University Press, 2003. 